\title{
Natural feed contaminant zearalenone decreases the expressions of important pro- and anti-inflammatory mediators and mitogen-activated protein kinase/NF-kB signalling molecules in pigs
}

\author{
Gina Cecilia Pistol ${ }^{1 *}$, Mihail Alexandru Gras ${ }^{1}$, Daniela Eliza Marin ${ }^{1}$, Florentina Israel-Roming ${ }^{2}$, \\ Mariana Stancu ${ }^{1}$ and Ionelia Taranu ${ }^{1}$ \\ ${ }^{1}$ Laboratory of Animal Biology, National Institute for Research and Development for Biology and \\ Animal Nutrition, Calea Bucuresti No. 1, Balotesti, Ilfov 077015, Romania \\ ${ }^{2}$ Biotechnology Department, University of Agriculture and Veterinary Medicine, Bulevardul Marasti No. 59, \\ Bucharest 011464, Romania
}

(Submitted 28 January 2013 - Final revision received 11 July 2013 - Accepted 16 July 2013 - First published online 20 August 2013)

\section{Abstract}

Zearalenone (ZEA) is an oestrogenic mycotoxin produced by Fusarium species, considered to be a risk factor from both public health and agricultural perspectives. In the present in vivo study, a feeding trial was conducted to evaluate the in vivo effect of a ZEA-contaminated diet on immune response in young pigs. The effect of ZEA on pro-inflammatory (TNF- $\alpha$, IL- 8 , IL- 6 , IL-1 $\beta$ and interferon- $\gamma$ ) and antiinflammatory (IL-10 and IL-4) cytokines and other molecules involved in inflammatory processes (matrix metalloproteinases (MMP)/ tissue inhibitors of matrix metalloproteinases (TIMP), nuclear receptors: PPAR $\gamma$ and NF- $\mathrm{KB} 1$, mitogen-activated protein kinases (MAPK): mitogen-activated protein kinase kinase kinase 7 (TAK1)/mitogen-activated protein kinase 14 (p38 $\alpha$ )/mitogen-activated protein kinase 8 (JNK1)/ mitogen-activated protein kinase 9 (JNK2)) in the liver of piglets was investigated. The present results showed that a concentration of 316 parts per billion ZEA leads to a significant decrease in the levels of pro- and anti-inflammatory cytokines at both gene expression and protein levels, correlated with a decrease in the levels of other inflammatory mediators, MMP and TIMP. The results also showed that dietary ZEA induces a dramatic reduction in the expressions of $N F-\kappa B 1$ and TAK1/p38 2 MAPK genes in the liver of the experimentally intoxicated piglets, and has no effect on the expression of PPAR $\gamma$ mRNA. The present results suggest that the toxic action of ZEA begins in the upstream of the MAPK signalling pathway by the inhibition of TAK1, a MAPK/NF-KB activator. In conclusion, the present study shows that ZEA alters several important parameters of the hepatic cellular immune response. From an economic point of view, these data suggest that, in pigs, ZEA is not only a powerful oestrogenic mycotoxin but also a potential hepatotoxin when administered through the oral route. Therefore, the present results represent additional data from cellular and molecular levels that could be taken into account in the determination of the regulation limit of the tolerance to ZEA.

Key words: Zearalenone: Pigs: Immune responses: Liver: Signalling pathways

Zearalenone (ZEA) is a non-steroidal oestrogenic mycotoxin synthesised by a variety of Fusarium fungi, including F. graminearum (Gibberella zeae), F. culmorum, F. cerealis, $F$. equiseti, $F$. crookwellense and $F$. semitectum, which are common soil fungi, in temperate and warm countries, being regular contaminants of cereal crops worldwide ${ }^{(1-5)}$. Toxin production mainly takes place before harvest, but it may also occur after harvest if the crop is not handled and dried properly $^{(6)}$. ZEA is also commonly found as a contaminant of stored grains, and the toxin has been detected in cereal products such as flour, malt, soyabeans and beer.
It is well known that ZEA has oestrogenic effects on mammals, being a risk factor from both public health and agricultural perspectives. The major target of this mycotoxin is the reproductive system ${ }^{(7)}$ because of the structural similarity of ZEA and some of its metabolites with the oestrogen hormones. It has been shown that ZEA competitively binds to oestrogen receptors and causes alterations in the reproductive tract of laboratory (mice, rats, guinea pigs, hamsters and rabbits) and domestic animals in a number of in vitro or in vivo systems ${ }^{(8-10)}$. ZEA has also been shown to be genotoxic, inducing DNA-adduct formation in in vitro cultures of

\footnotetext{
Abbreviations: DON, deoxynivalenol; IFN- $\boldsymbol{\gamma}$, interferon- $\boldsymbol{\gamma}$; JNK1, mitogen-activated protein kinase 8; JNK2, mitogen-activated protein kinase 9; MAPK, mitogen-activated protein kinases; MMP, matrix metalloproteinases; p38 $\alpha$, mitogen-activated protein kinase 14; ppb, parts per billion; TAK1, mitogenactivated protein kinase kinase kinase 7; Th, T helper; TIMP, tissue inhibitors of matrix metalloproteinases; ZEA, zearalenone.
} 
bovine lymphocytes ${ }^{(11)}$, DNA fragmentation and micronucleus production in cultured cells ${ }^{(12,13)}$. In addition, ZEA has been shown to be immunotoxic ${ }^{(14-16)}$ and hepatonephrotoxic ${ }^{(17,18)}$ and an enhancer of lipid peroxidation ${ }^{(19)}$. Once ZEA enters the body, it is mainly metabolised in the liver ${ }^{(20)}$, which seems to be one of the main targets of the toxin ${ }^{(21)}$, and its derivatives discharge in the kidney ${ }^{(22)}$. ZEA is able to induce liver lesions with subsequent development of hepatocarcinoma ${ }^{(23)}$ and alterations of some enzymatic parameters of the hepatic function in rats ${ }^{(24)}$, rabbits $^{(25)}$ and gilts ${ }^{(26)}$. Moreover, ZEA is an activator of human pregnane $X$ receptor, a transcription factor that regulates the expressions of many hepatic drugmetabolising enzymes, including several clinically important cytochrome P450. ZEA concentration-response analyses reveal that the mycotoxin activates human pregnane $\mathrm{X}$ receptor with an $\mathrm{EC}_{50}$ value of approximately $1.5 \mu \mathrm{m}^{(27)}$.

Pigs are generally considered to be the most sensitive animal species to ZEA and its metabolites ${ }^{(15,28)}$. ZEA intoxication is associated with decreased fertility, reduced litter size, change in the weight of adrenal, thyroid and pituitary glands in offspring and change in the serum levels of progesterone and oestradiol ${ }^{(28)}$. Recently, ZEA and its derivatives have been demonstrated to have divergent effects on important parameters of swine innate immunity and have been described as the modulators of the expressions of pro-inflammatory cytokines in peripheral circulating blood cells ${ }^{(29-31)}$. Despite these aspects, only a few studies focusing on the hepato- and immunomodulatory effects of ZEA in swine have been reported, especially an in-depth analysis of these effects. However, the histopathological results provide evidence of liver dysfunction such as significant reduction in the levels of total superoxide dismutase and of glutathione peroxidase activity and increase in the levels of malondialdehyde $^{(21)}$. To our knowledge, there are no studies on the effects of dietary ZEA corroborated with the mode of action of ZEA in the liver of swine. For many contaminants of the agro-food chain (ZEA being among them), there are no norms of tolerance (only recommendations) issued by the European Commission, and recently the European Food Safety Authority ${ }^{(32)}$ has recommended that in-depth studies be conducted to determine that not just the readily visible alterations in performance, but also the deeper changes at the cellular and molecular levels are taken into account when determining the doses accepted as maximal limits; this is so, because they may have long-term consequences on animal health and economic repercussions such as the failure of some treatments or vaccinations.

Using in vivo approaches and new molecular biology techniques (real-time PCR), the aim of the present study was to obtain a better insight into the changes produced by this toxin in the expressions of several markers responsible for important defence processes (inflammation and T-helper (Th)1/Th2 pathway regulation) in the liver as the key organ in immune homeostasis and in the detoxification of food contaminants, pharmaceutical substances and xenobiotics. The possible mechanism of ZEA action is suggested.

\section{Materials and methods}

\section{Animals and treatments}

A total of ten TOPIGS-40 cross-bred weanling piglets ( $n 5$ per group) with an initial average body weight of 9.5 (SEM 0.6$) \mathrm{kg}$ and age of $35 \mathrm{~d}$ were studied for $18 \mathrm{~d}$. The piglets that were individually identified by ear tags were divided into two groups ( $n 5$ piglets/group per pen) and housed in pens and were allocated to the following two dietary treatments: (1) control (maize-soyabean meal basal diet only) ${ }^{(33)}$ and (2) ZEA (control diet contaminated with 250 parts per billion (ppb) ZEA). Feed samples were taken at the beginning of the experiment and were analysed for Fusarium mycotoxin and nutrient content. During the experiment, the piglets were given ad libitum access to water and to the assigned diets. At the end of experiment, the piglets were weighed individually and cumulative feed consumption was measured for each pen. In order to study the effect of ZEA treatment on hepatic immune response, the piglets were killed at the end of the trial and liver samples were collected on ice from all the piglets and an aliquot $(30-50 \mathrm{~g})$ was stored at $-80^{\circ} \mathrm{C}$ until analysis. The piglets were observed twice daily and cared for in accordance with the Romanian Law 206/2004 for handling and protection of animals used for experimental purposes. The study protocol was approved by the Ethical Committee of the National Research-Development Institute for Biology and Animal Nutrition, Balotesti, Romania.

\section{Analysis of mycotoxins}

The content of ZEA in the feed was analysed by HPLC with fluorescence detection after clean-up with an immunoaffinity column (Inertsil ODS-3 V; GL Sciences, Inc.) at a detection limit of $6 \mathrm{ng} / \mathrm{g}$. The contaminated diet contained 316.0 (SEM 30.9) $\mathrm{ppb}$ of ZEA, whereas the control diet contained 40.92 (sEm $0 \cdot 15$ ) ppb of ZEA in compound feed, without contamination with other Fusarium toxins. ELISA using a Veratox ELISA kit (Neogen) with detection limits of 100, 200, 10, 1 and $0.5 \mathrm{ppb}$, respectively, was carried out to detect for the presence of deoxynivalenol(DON), fumonisin B1, T-2/HT-2, ochratoxin A and aflatoxin toxins, and none of them was detected.

\section{Measurement of cytokine production}

Samples of frozen liver were weighed, and $500 \mathrm{mg}$ of tissue samples were homogenised in phosphate buffer containing $1 \%$ IGEPAL, $0 \cdot 5 \%$ sodium deoxycholate, $0 \cdot 1 \%$ SDS and complete (EDTA-free) protease inhibitor cocktail tablets. The homogenates were kept on ice for $30 \mathrm{~min}$ and then centrifuged at $10000 \mathrm{rpm}$ at $4{ }^{\circ} \mathrm{C}$ for $10 \mathrm{~min}$. The supernatants were analysed for protein content using a commercial kit (Pierce ${ }^{\circledR}$ BCA Protein Assay Kit; Thermo Fisher Scientific), and the concentrations of cytokines in the supernatants were determined by ELISA, using commercially available kits (R\&D Systems), according to the manufacturer's instructions ${ }^{(30)}$ Optical densities were measured on an ELISA reader (Tecan) at a wavelength of $450 \mathrm{~nm}$. Dilutions of recombinant swine IL-1 $\beta$, IL-8, TNF- $\alpha$, IL-4, IL-6, IL-10 and interferon- $\gamma$ (IFN- $\gamma$ ) 
were used as standards, and data were analysed against the linear portion of the generated standard curve. Results are expressed as pg cytokine/ml supernatant.

\section{Measurement of matrix metalloproteinase-2 and matrix metalloproteinase-9 gelatinase activity}

Frozen liver samples of $50 \mathrm{mg}$ were weighed and homogenised for $30 \mathrm{~min}$ on ice in a lysis buffer $(50 \mathrm{~mm}$-Tris, $\mathrm{pH} 7 \cdot 5$, $1 \%$ Triton X-100, $250 \mathrm{~mm}-\mathrm{NaCl}, 10 \%$ glycerol and complete EDTA-free protease inhibitor cocktail tablets). The homogenates were centrifuged at $1200 \mathrm{rpm}$ for $10 \mathrm{~min}$ at $4^{\circ} \mathrm{C}$, and the supernatants were re-centrifuged at $15000 \mathrm{rpm}$ for $15 \mathrm{~min}$ at $4^{\circ} \mathrm{C}$. Finally, the resultant supernatants were analysed for total protein content using a commercial kit, and the aliquots were frozen at $-80^{\circ} \mathrm{C}$ until processing. The determination of gelatinase activity of matrix metalloproteinase (MMP)-2 and MMP-9 in the liver and plasma samples was done using zymography, realised by SDS-PAGE in the presence of $0.1 \%$ gelatin $^{(34)}$. After electrophoresis, the proteins were renatured by incubating the gel in $2.5 \%$ Triton $\mathrm{X}-100$ for $30 \mathrm{~min}$. The activity of gelatinase was developed by incubating the gel for $18 \mathrm{~h}$ at $37^{\circ} \mathrm{C}$ in an enzymatic substrate containing $50 \mathrm{~mm}$-Tris, pH 7.4, with $5 \mathrm{~mm}-\mathrm{CaCl}_{2}$ and $0 \cdot 2 \mathrm{~mm}^{-\mathrm{NaCl}_{2}}$. The lytic activity of gelatinase was visualised, after staining the gel with Coomassie Brilliant Blue, as a clear lane on a blue background. The gelatin zymograms were scanned and matrix metalloproteinase activities were quantified using the Total Lab Quant software (TotalLab Limited). All densitometry results are expressed as arbitrary units.

\section{Immunoblot assays}

Samples of frozen liver were weighed, and $500 \mathrm{mg}$ of tissue samples were homogenised in phosphate buffer containing $1 \%$ IGEPAL, $0 \cdot 5 \%$ sodium deoxycholate, $0 \cdot 1 \%$ SDS and complete (EDTA-free) protease inhibitor cocktail tablets. The homogenates were kept on ice for $30 \mathrm{~min}$ and then centrifuged at $10000 \mathrm{rpm}$ at $4^{\circ} \mathrm{C}$ for $10 \mathrm{~min}$. The resultant supernatants were analysed for total protein content using a commercial kit (Pierce ${ }^{\circledR}$ BCA Protein Assay Kit; Thermo Fisher Scientific), and the aliquots were frozen at $-80^{\circ} \mathrm{C}$ until processing. Immunoblot assays were used to analyse the expression of phospho-p38 mitogen-activated protein kinases (MAPK) in the lysed liver tissue samples. Later, $25 \mu \mathrm{g}$ of total proteins were separated on $10 \%$ SDS-PAGE and transferred onto nitrocellulose membranes. The membranes were blocked with Tris-buffered saline $(\mathrm{pH} 7.5)$ and 5\% bovine serum albumin and incubated with primary antibodies for $2 \mathrm{~h}$ at room temperature. Rabbit anti-phospho-p38 MAPK (Thr180/Tyr182) antibodies (diluted 1:200) were obtained from Cell Signaling Technology. Rabbit anti- $\beta$-actin antibodies (Cell Signaling Technology), diluted 1:500, were used as the control. The membranes were then washed and incubated for $1 \mathrm{~h}$ with secondary antibodies, goat anti-rabbit IgG conjugated with horseradish peroxidase, diluted 1:2000 (Cell Signaling Technology). Immunoreactivity was detected using the SuperSignal* West Pico Chemiluminescent Substrate developing system (Thermo Fisher Scientific). Immunoblotting images were scanned, and the level of proteins was evaluated using the Total Lab Quant software (TotalLab Limited). The results are expressed as the ratio of the phosphorylation level of p38 MAPK to the expression level of $\beta$-actin.

\section{Extraction of total RNA}

Frozen liver tissue samples of $100 \mathrm{mg}$ were disrupted and homogenised in RTL buffer (QIAGEN GmbH) using an Ultra-Turrax homogeniser (IKA ${ }^{\circledR}$-Werke GmbH \& Co. KG). Total RNA was extracted using a Qiagen RNeasy midi kit (QIAGEN GmbH), according to the manufacturer's recommendations. After extraction, RNA was treated with a ribonuclease inhibitor (RNasin ${ }^{\circledR}$ Plus RNase Inhibitor; Promega Corporation), and the quantity and quality of the extracted total RNA were measured on a Nanodrop ND-1000 spectrophotometer (Thermo Fisher Scientific). The integrity of RNA was verified by agarose gel electrophoresis.

\section{Complementary DNA synthesis}

Total RNA from each sample was used to generate complementary DNA using the M-MuLV Reverse Transcriptase kit (Fermentas; Thermo Fisher Scientific) according to the manufacturer's protocol. Briefly, $1 \mu \mathrm{g}$ of total RNA was used as the starting material, to which $0.5 \mu \mathrm{g}$ of oligo-(deoxythymine) was added. RNA and oligo-(deoxythymine) were mixed gently and then centrifuged and incubated at $65^{\circ} \mathrm{C}$ for $5 \mathrm{~min}$, chilled on ice, centrifuged and again placed on ice. The following components were added later: $4 \mu \mathrm{l}$ of $5 \times$ reaction buffer; $2 \mu$ l of deoxyribonucleotide triphosphate mix ( $1 \mathrm{~mm}$ of each deoxyribonucleotide triphosphate); $2 \mu$ l of Moloney murine leukaemia virus (MMULV) RT ( $40 \mathrm{U}$ ). The samples were incubated at $42^{\circ} \mathrm{C}$ for $60 \mathrm{~min}$, and the reaction mixtures were inactivated at $70^{\circ} \mathrm{C}$ for $10 \mathrm{~min}$.

\section{Quantitative real-time PCR}

Fluorescent real-time PCR was used to evaluate the expressions of pro-inflammatory (TNF- $\alpha I L-1 \beta, I L-8$ and $I F N-\gamma)$ and anti-inflammatory (IL-4, IL-6 and $I L-10)$ cytokines, MMP (MMP-2 and $M M P-9)$, tissue inhibitors of matrix metalloproteinases (TIMP-1 and TIMP-2), PPAR $\gamma$ and $M A P K / N F-\kappa B 1$ genes. The reaction mixtures were set up at a total volume of $20 \mu \mathrm{l}$ using $5 \mu \mathrm{l}$ of complementary DNA (diluted 1:10), $12.5 \mu \mathrm{l}$ Maxima SYBR Green/Fluorescein qPCR Master Mix 2X (Fermentas; Thermo Fisher Scientific) and $0.3 \mu \mathrm{M}$ of each gene-specific primer (Table 1 ), and the reactions were carried out in the Rotor-Gene-Q (QIAGEN GmbH) machine. The cycling conditions were as follows: uracil-DNA glycosylase (UDG) pre-treatment at $50^{\circ} \mathrm{C}$ for $2 \mathrm{~min}$; initial denaturation step at $95^{\circ} \mathrm{C}$ for $15 \mathrm{~s}$, followed by forty cycles of $95^{\circ} \mathrm{C}$ for $15 \mathrm{~s}, 60^{\circ} \mathrm{C}$ for $15 \mathrm{~s}$ and $72^{\circ} \mathrm{C}$ for $15 \mathrm{~s}$ with a single fluorescence measurement; a final elongation step at $72^{\circ} \mathrm{C}$ for $10 \mathrm{~min}$. The specificity of the PCR products was confirmed by analysis of the dissociation curve. The melting curve programme consisted of temperatures between 60 and $95^{\circ} \mathrm{C}$ with a heating rate of $0 \cdot 1{ }^{\circ} \mathrm{C} / \mathrm{s}$ and a continuous fluorescence measurement. 
Table 1. Nucleotide sequences of primers used in real-time PCR

\begin{tabular}{|c|c|c|c|c|c|c|c|}
\hline Genes & Accession no. & $\begin{array}{l}\text { Primer } \\
\text { source }\end{array}$ & Primer sequence $\left(5^{\prime} \rightarrow 3^{\prime}\right)$ & $\begin{array}{l}\text { Orien- } \\
\text { tation }\end{array}$ & $\begin{array}{l}\text { Tempe- } \\
\text { rature }\left({ }^{\circ} \mathrm{C}\right)\end{array}$ & $\begin{array}{l}\text { Amplicon } \\
\text { length (bp) }\end{array}$ & References \\
\hline$T N F-\alpha$ & NM_214022 & Pig & $\begin{array}{l}\text { ACTGCACTTCGAGGTTATCGG } \\
\text { GGCGACGGGCTTATCTGA }\end{array}$ & $\begin{array}{l}\text { Forward } \\
\text { Reverse }\end{array}$ & $\begin{array}{l}60 \\
60\end{array}$ & 118 & $\begin{array}{l}\text { Von der Hardt } \\
\text { et al. }{ }^{(35)}\end{array}$ \\
\hline IL-8 & NM_213867·1 & Pig & $\begin{array}{l}\text { GCTCTCTGTGAGGCTGCAGTTC } \\
\text { AAGGTGTGGAATGCGTATTTATGC }\end{array}$ & $\begin{array}{l}\text { Forward } \\
\text { Reverse }\end{array}$ & $\begin{array}{l}58 \\
54\end{array}$ & 79 & $\begin{array}{l}\text { Von der Hardt } \\
\quad \text { et al. }{ }^{(35)}\end{array}$ \\
\hline IL-6 & NM_214399 & Pig & $\begin{array}{l}\text { GGCAAAAGGGAAAGAATCCAG } \\
\text { CGTTCTGTGACTGCAGCTTATCC }\end{array}$ & $\begin{array}{l}\text { Forward } \\
\text { Reverse }\end{array}$ & $\begin{array}{l}57 \\
61\end{array}$ & 87 & $\begin{array}{l}\text { Von der Hardt } \\
\quad \text { et al. }{ }^{(35)}\end{array}$ \\
\hline$I L-1 \beta$ & NM_214055 & Pig & $\begin{array}{l}\text { ATGCTGAAGGCTCTCCACCTC } \\
\text { TTGTTGCTATCATCTCCTTGCAC }\end{array}$ & $\begin{array}{l}\text { Forward } \\
\text { Reverse }\end{array}$ & $\begin{array}{l}62 \\
59\end{array}$ & 89 & Royaee et al. ${ }^{(36)}$ \\
\hline IL-10 & NM_214041.1 & Pig & $\begin{array}{l}\text { GGCCCAGTGAAGAGTTTCTTTC } \\
\text { CAACAAGTCGCCCATCTGGT }\end{array}$ & $\begin{array}{l}\text { Forward } \\
\text { Reverse }\end{array}$ & $\begin{array}{l}54 \\
55\end{array}$ & 51 & $\begin{array}{l}\text { Von der Hardt } \\
\text { et al. }{ }^{(35)}\end{array}$ \\
\hline$I F N-\gamma$ & NM_213948.1 & Pig & $\begin{array}{l}\text { TGGTAGCTCTGGGAAACTGAATG } \\
\text { GGCTTTGCGCTGGATCTG }\end{array}$ & $\begin{array}{l}\text { Forward } \\
\text { Reverse }\end{array}$ & $\begin{array}{l}54 \\
55\end{array}$ & 79 & Meurens et al. ${ }^{(37)}$ \\
\hline$I L-4$ & NM_214123.1 & Pig & $\begin{array}{l}\text { CAACCCTGGTCTGCTTACTG } \\
\text { CTTCTCCGTCGTGTTCTCTG }\end{array}$ & $\begin{array}{l}\text { Forward } \\
\text { Reverse }\end{array}$ & $\begin{array}{l}52 \\
52\end{array}$ & 173 & Zeni et al. ${ }^{(38)}$ \\
\hline MMP-2 & NM_214192·1 & Pig & $\begin{array}{l}\text { GGCTTGTCACGTGGTGTCACT } \\
\text { ATCCGCGGCGAGATCTTCT }\end{array}$ & $\begin{array}{l}\text { Forward } \\
\text { Reverse }\end{array}$ & $\begin{array}{l}57 \\
55\end{array}$ & 68 & Singh et al. ${ }^{(39)}$ \\
\hline MMP-9 & NM_001038004.1 & Pig & $\begin{array}{l}\text { GAAGCTTTAGAGCCGGTTCCA } \\
\text { GGCAGCTGGCAGAGGAATATC }\end{array}$ & $\begin{array}{l}\text { Forward } \\
\text { Reverse }\end{array}$ & $\begin{array}{l}55 \\
55\end{array}$ & 96 & Singh et al. ${ }^{(39)}$ \\
\hline TIMP-1 & NM_213857·1 & Pig & $\begin{array}{l}\text { CAAAACTGCAGGTGGTGATGTG } \\
\text { CGCAGCCAGGAGTTTCTCAT }\end{array}$ & $\begin{array}{l}\text { Forward } \\
\text { Reverse }\end{array}$ & $\begin{array}{l}55 \\
55\end{array}$ & 70 & Singh et al. ${ }^{(39)}$ \\
\hline TIMP-2 & NM_001145985.1 & Pig & $\begin{array}{l}\text { CAGGTACCAGATGGGCTGTGA } \\
\text { ACTCGTCCGGAGAGGAGATGTAG }\end{array}$ & $\begin{array}{l}\text { Forward } \\
\text { Reverse }\end{array}$ & $\begin{array}{l}56 \\
57\end{array}$ & 77 & Singh et al. ${ }^{(39)}$ \\
\hline$P P A R \gamma$ & NM_214379.1 & Pig & $\begin{array}{l}\text { ACTGTCGGTTTCAGAAGTGC } \\
\text { CAGCAGACTCTGGGTTCAGT }\end{array}$ & $\begin{array}{l}\text { Forward } \\
\text { Reverse }\end{array}$ & $\begin{array}{l}53 \\
53\end{array}$ & 138 & Primer $3^{(40)}$ \\
\hline TAK1 & NM_001114280.1 & Pig & $\begin{array}{l}\text { TGCCCAAACTCCAAAGAATC } \\
\text { TTTGCTGGTCCTTTTCATCC }\end{array}$ & $\begin{array}{l}\text { Forward } \\
\text { Reverse }\end{array}$ & $\begin{array}{l}56 \\
56\end{array}$ & 151 & Gesslein et al. ${ }^{(41)}$ \\
\hline$p 38 \alpha$ & XM_003356616.1 & Pig & $\begin{array}{l}\text { TGCAAGGTCTCTGGAGGAAT } \\
\text { CTGAACGTGGTCATCCGTAA }\end{array}$ & $\begin{array}{l}\text { Forward } \\
\text { Reverse }\end{array}$ & $\begin{array}{l}52 \\
52\end{array}$ & 109 & $\begin{array}{l}\text { Chowdhury } \\
\text { et al. }{ }^{(42)}\end{array}$ \\
\hline JNK1 & XM_003359272.1 & Pig & $\begin{array}{l}\text { TGCTTTGTGGAATCAAGCAC } \\
\text { TGGGCTTTAAGTCCCGATG }\end{array}$ & $\begin{array}{l}\text { Forward } \\
\text { Reverse }\end{array}$ & $\begin{array}{l}51 \\
51\end{array}$ & 60 & $\begin{array}{l}\text { Chowdhury } \\
\text { et al. }^{(42)}\end{array}$ \\
\hline JNK2 & XM_003354171.2 & Pig & $\begin{array}{l}\text { TATTATCGGGCACCAGAAGTC } \\
\text { AACCTTTCACCAGCTCTCTCA }\end{array}$ & $\begin{array}{l}\text { Forward } \\
\text { Reverse }\end{array}$ & $\begin{array}{l}51 \\
53\end{array}$ & 97 & $\begin{array}{l}\text { Chowdhury } \\
\text { et al. }{ }^{(42)}\end{array}$ \\
\hline$N F-\kappa B 1$ & NM_001048232.1 & Pig & $\begin{array}{l}\text { TCGCTGCCAAAGAAGGACAT } \\
\text { AGCGTTCAGACCTTCACCGT }\end{array}$ & $\begin{array}{l}\text { Forward } \\
\text { Reverse }\end{array}$ & $\begin{array}{l}54 \\
56\end{array}$ & 101 & Devriendt et al. ${ }^{(43)}$ \\
\hline Cyclophilin A & NM_214353.1 & Pig & $\begin{array}{l}\text { CCCACCGTCTTCTTCGACAT } \\
\text { TCTGCTGTCTTTGGAACTTTGTCT }\end{array}$ & $\begin{array}{l}\text { Forward } \\
\text { Reverse }\end{array}$ & $\begin{array}{l}54 \\
55\end{array}$ & 92 & Hyland et al. ${ }^{(44)}$ \\
\hline$\beta 2$-Microglobulin & NM_213978·1 & Pig & $\begin{array}{l}\text { TTCTACCTTCTGGTCCACACTGA } \\
\text { TCATCCAACCCAGATGCA }\end{array}$ & $\begin{array}{l}\text { Forward } \\
\text { Reverse }\end{array}$ & $\begin{array}{l}55 \\
50\end{array}$ & 162 & $\begin{array}{l}\text { Litvak \& } \\
\quad \text { Schmittgen } \\
\end{array}$ \\
\hline
\end{tabular}

IFN- $\gamma$, interferon- $\gamma$; MMP, matrix metalloproteinases; TIMP, tissue inhibitors of matrix metalloproteinases; TAK1, mitogen-activated protein kinase kinase kinase $7 ; p 38 \alpha$, mitogen-activated protein kinase 14; JNK1, mitogen-activated protein kinase 8; JNK2, mitogen-activated protein kinase 9.

All samples were measured in triplicate. The relative product levels were quantified using the $2^{\left(-\Delta \Delta C_{\mathrm{T}}\right)} \operatorname{method}^{(46)}$. The expression levels of two endogenous control genes, cyclophilin $\mathrm{A}$ and $\beta 2$-microglobulin, were used for data normalisation.

\section{Statistical analysis}

All data are expressed as means with their standard errors. ANOVA and $t$ test analysis were carried out to investigate the statistical differences between the groups for all the parameters analysed. Further differences between the means were determined using the least square difference Fisher procedure. A simple regression $\left(y=a x^{2}+b\right)$ procedure (StatView software; SAS Institute, Inc.) was used to establish correlations between the gene expressions of signalling (PPAR $\gamma, N F-\kappa B 1$ and $M A P K)$ and inflammationrelated $(I L-1 \beta, I L-8, T N F-\alpha, I L-4, I L-6$ and $I L-10)$ molecules in the liver of piglets that were given dietary mycotoxin. Briefly, correlations between nuclear receptors (PPAR $\gamma$ and NF-кB1), MAPK (mitogen-activated protein kinase kinase kinase 7 (TAK1)/ mitogen-activated protein kinase 14 (p38 $\alpha$ )/mitogen-activated protein kinase $8(\mathrm{JNK} 1) /$ mitogen-activated protein kinase 9
(JNK2)) as independent variables ( $y$ ) and inflammation-related markers as dependent variables $(x)$ were established. Values of $P<0.05$ were considered significant.

\section{Results}

\section{Effect of zearalenone on animal performance}

Piglets fed the control or ZEA-contaminated diet appeared to be clinically normal during the whole experimental period; at the end of the trial, average daily gain $(0.367 \mathrm{v}$. $0.344 \mathrm{~kg} /$ piglet per $\mathrm{d}, P=0.58)$, daily feed intake $(0.681 v$. $0.716 \mathrm{~kg} /$ piglet per $\mathrm{d}, P=0.41)$ or feed:gain ratio $(1.87 v .2 \cdot 17$, $P=0 \cdot 25)$ was not influenced by the dietary treatments.

Dietary zearalenone modulates the concentrations and gene expressions of pro- and anti-inflammatory cytokines in swine liver

First, we examined the in vivo effect of ZEA on the proinflammatory cytokine profile as a marker of inflammation. 


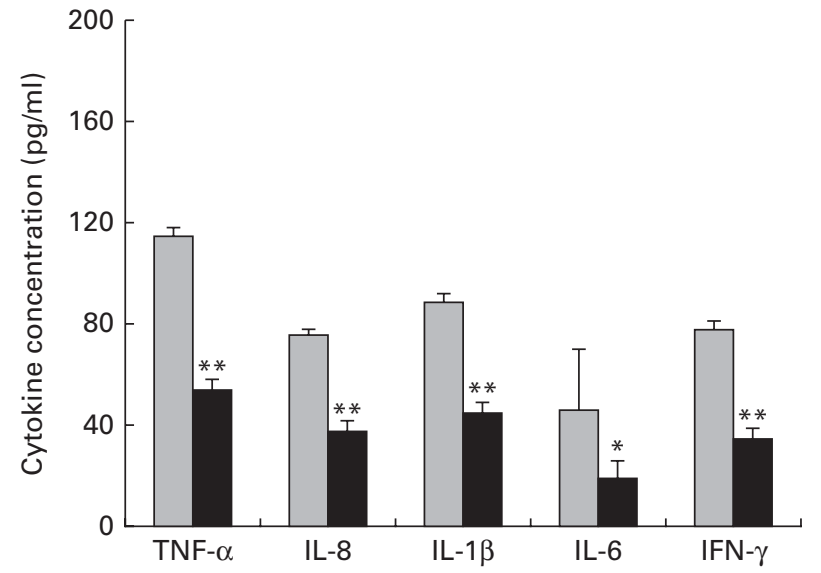

Fig. 1. Effects of the zearalenone (ZEA)-contaminated diet on the synthesis of cytokines, TNF- $\alpha$, IL- 8, IL- $-1 \beta$, IL- 6 and interferon- $\gamma$ (IFN- $\gamma$ ), in the liver of piglets. The supernatants were analysed for total protein content, using a commercial kit. The concentrations of TNF- $\alpha$, IL- 8, IL- $-1 \beta$, IL- 6 and IFN- $\gamma$ in the supernatants were determined by ELISA using R\&D Systems kits (R\&D Systems), according to the manufacturer's instructions. Optical densities were measured on an ELISA reader (Tecan) at a wavelength of $450 \mathrm{~nm}$. Results are expressed as $\mathrm{pg} / \mathrm{ml}$, and they were normalised to total protein concentration. Values are means $(n 5)$, with their standard errors represented by vertical bars. Mean value of the ZEA-contaminated group $(\square)$ was significantly different from that of the control group $(\square)$ : ${ }^{\star} P<0.05$, ${ }^{\star \star} P<0.001$ (one-way ANOVA test).

The present results clearly showed a strong decrease in the protein concentrations of TNF- $\alpha$, IL- 8 , IL- 6 , IL- $1 \beta$ and IFN- $\gamma$ in the liver of piglets treated with ZEA when compared with the control piglets (TNF- $\alpha$ : $-52.76 \%$; IL-8: $-49.79 \%$; IL-6: $-58.05 \%$; IL-1 $\beta$ : $-49 \cdot 73 \%$; IFN- $\gamma$ : $-54.81 \%$, respectively) (Fig. 1). The alteration in the levels of pro-inflammatory markers caused by ZEA was more profound, also being observed at the mRNA expression level (TNF- $\alpha$ : $-83.44 \%$;

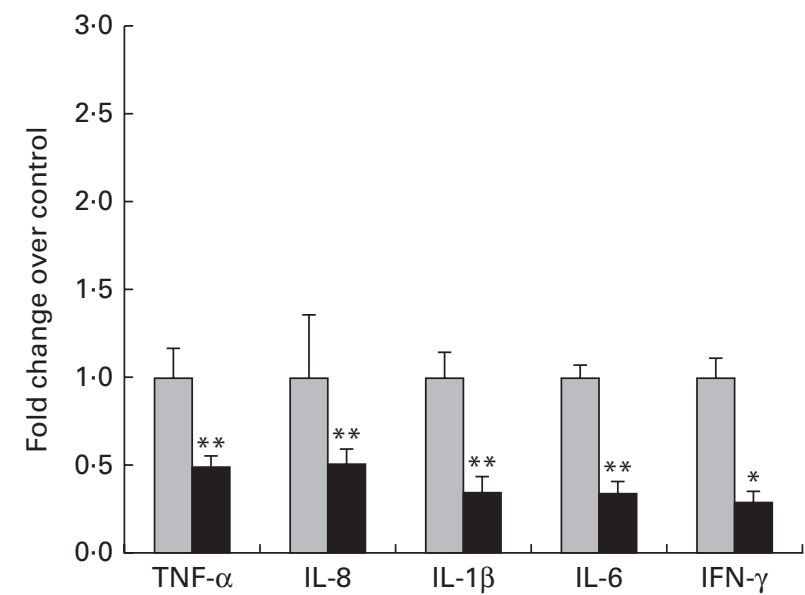

Fig. 2. Influence of dietary zearalenone (ZEA) on the expressions of proinflammatory cytokine genes and interferon- $\gamma$ mRNA in the liver of piglets. Liver samples were analysed for the mRNA expressions of cytokines using quantitative real-time PCR. Results are expressed as fold changes after normalisation of the expression of target cytokine gene to the arithmetic mean of two internally expressed reference genes. Values are means from three independent replicates, with their standard errors represented by vertical bars. Mean value of the ZEA-contaminated group ( $\square$ ) was significantly different from that of the control group $(\square)$ : ${ }^{\star} P<0.05$, ${ }^{* *} P<0.001$ (one-way ANOVA followed by Fisher's test).
Table 2. Effect of in vivo exposure of piglets to zearalenone (ZEA) on the protein levels of anti-inflammatory cytokines in the hepatic tissue (Mean values with their standard errors)

\begin{tabular}{|c|c|c|c|c|c|}
\hline \multirow{3}{*}{$\begin{array}{l}\text { Cytokine } \\
\text { concentrations } \\
(\mathrm{pg} / \mathrm{ml})\end{array}$} & \multicolumn{5}{|c|}{ Experimental groups $†$} \\
\hline & \multicolumn{2}{|c|}{ Control } & \multicolumn{2}{|c|}{$\begin{array}{c}\text { ZEA } \\
\text { contamination }\end{array}$} & \multirow{2}{*}{$\begin{array}{c}\text { ZEA effec } \\
P\end{array}$} \\
\hline & Mean & SEM & Mean & SEM & \\
\hline$I L-10$ & $45 \cdot 98$ & $6 \cdot 8$ & $22 \cdot 67^{*}$ & $6 \cdot 2$ & $<0.001$ \\
\hline IL-4 & $49 \cdot 14$ & $4 \cdot 2$ & $20.51^{*}$ & $2 \cdot 4$ & $<0.0001$ \\
\hline
\end{tabular}

* Mean value was significantly different from that of the control group $(P<0.05$; one-way ANOVA followed by Fisher's test).

†Piglets were fed a control diet or a diet contaminated with $316 \mu \mathrm{g}$ ZEA $/ \mathrm{kg}$ diet for $18 \mathrm{~d}$. At the end of the experiment, liver samples from all the piglets $(n 5)$ were collected and analysed for the levels of cytokines using ELISA.

$I L-8: \quad-63.68 \% ; \quad I L-6:-92.68 \% ; \quad I L-1 \beta: \quad-85.06 \% ; \quad I F N-\gamma$ : $-88.85 \%$, respectively) (Fig. 2 ). The protein concentrations and expressions of cytokines known to be involved in antiinflammatory reactions, IL-10 and IL-4, were then analysed in order to get a comprehensive picture of the effects of ZEA on swine cytokine response with possible repercussion on Th1/Th2 cytokine balance. The concentrations of both IL-10 and IL- 4 in the liver decreased significantly by -50.69 and $-58 \cdot 26 \%$, respectively (Table 2). The expression of $I L-4$ mRNA was also significantly reduced in the liver of piglets treated with dietary ZEA $(-89.95 \%, P<0.0001)$, while that of $I L-1 O$ gene in the liver of piglets fed the ZEA-contaminated diet was unmodified in comparison with the control piglets $(-0.87 \%)$ (Table 3)

\section{Dietary zearalenone modulates the activity of matrix metalloproteinases and their inhibitors in swine liver}

The next step in the trial was to determine the effect of ZEA on MMP as important molecules involved in inflammatory processes that are closely associated with the cytokine network. Gelatin zymography technique was used to investigate MMP activity in the liver and plasma samples. Densitometric analysis of the scanned zymograms (Fig. 3) showed that

Table 3. Effect of in vivo exposure of piglets to zearalenone (ZEA) on the gene expressions of anti-inflammatory cytokines in the hepatic tissue (Mean values with their standard errors)

\begin{tabular}{|c|c|c|c|c|c|}
\hline \multirow{3}{*}{$\begin{array}{l}\text { Cytokine gene } \\
\text { expressions }\end{array}$} & \multicolumn{5}{|c|}{ Experimental groups $\dagger$} \\
\hline & \multicolumn{2}{|c|}{ Control } & \multicolumn{2}{|c|}{$\begin{array}{c}\text { ZEA } \\
\text { contamination }\end{array}$} & \multirow{2}{*}{$\begin{array}{c}\text { ZEA effec } \\
P\end{array}$} \\
\hline & Mean & SEM & Mean & SEM & \\
\hline$I L-10$ & 1.00 & 0.2 & 1.01 & 0.1 & NS \\
\hline$I L-4$ & 1.00 & 0.4 & $0.10^{*}$ & 0.1 & $<0.0001$ \\
\hline
\end{tabular}

${ }^{*}$ Mean value was significantly different from that of the control group $(P<0.05$; one-way ANOVA followed by Fisher's test).

†Piglets were fed a control diet or a diet contaminated with $316 \mu \mathrm{g} Z \mathrm{ZEA} / \mathrm{kg}$ diet for $18 \mathrm{~d}$. At the end of the experiment, liver samples from all the piglets $(n 5)$ were collected and analysed for the mRNA expressions of cytokines using quantitative real-time PCR.

$\ddagger$ Results are expressed as fold changes after normalisation of the expression of target cytokine gene to the arithmetic mean of two internally expressed reference genes. 


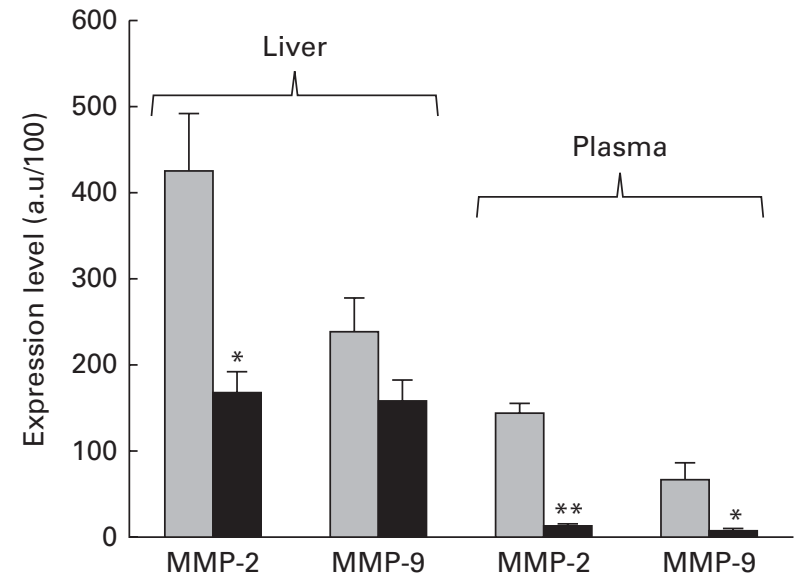

Fig. 3. Effects of dietary zearalenone (ZEA) on the activity of matrix metalloproteinases (MMP) in the liver tissue and plasma samples. Liver extracts were resolved on SDS-PAGE zymography using $0.1 \%$ gelatin. Results are expressed as arbitrary units (a.u.). Values are means, with their standard errors represented by vertical bars. Mean value of the ZEA-contaminated group $(\square)$ was significantly different from that of the control group $(\square)$ : ${ }^{*} P<0.05,{ }^{* *} P<0.001$ (one-way ANOVA test).

the activities of both MMP-2 and MMP-9 were corroborated with the gene expression analysis, being decreased in the liver of piglets fed the ZEA-contaminated diet $(-60.30 \%$ for MMP-2 and $-34 \cdot 10 \%$ for MMP-9) in comparison with the control group. The same profile of gelatinase activity was obtained for the plasma samples $(-90 \cdot 74 \%$ for MMP-2 and $-89.32 \%$ for MMP-9) (Fig. 3). The concentration of $316 \mu \mathrm{g}$ $\mathrm{ZEA} / \mathrm{kg}$ diet also led to a significantly marked decrease in the expressions of both hepatic MMP genes (MMP-2: $-81.55 \%$, $P<0.05$; MMP-9: $-96.37 \%, P<0.001$ ) (Fig. 4).

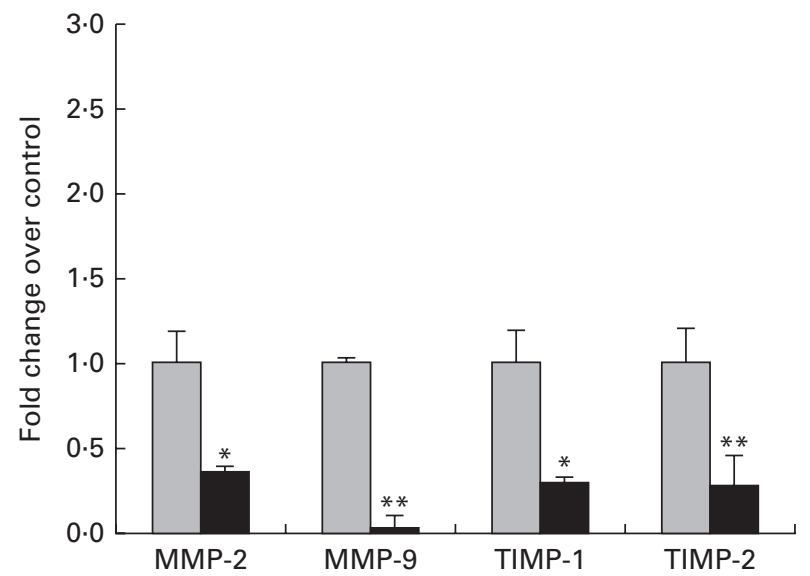

Fig. 4. Effects of zearalenone (ZEA) treatment on the gene expressions of matrix metalloproteinases (MMP)/tissue inhibitors of matrix metalloproteinases (TIMP) in the liver tissue samples. Liver samples were analysed for the expressions of MMP/TIMP mRNA using quantitative real-time PCR. Results are expressed as fold changes after normalisation of the expression of target cytokine gene to the arithmetic mean of two internally expressed reference genes. Values are the means from three independent replicates, with their standard errors represented by vertical bars. Mean value of the ZEA-contaminated group $(\square)$ was significantly different from that of the control group $(\square)$ : ${ }^{\star} P<0.05$, ${ }^{\star \star} P<0.001$ (one-way ANOVA followed by Fisher's test).
Knowing that TIMP are the most efficient natural inhibitors of MMP activity and secretion, we evaluated the gene expressions of two members of the TIMP family, TIMP-1 and TIMP-2, using quantitative real-time PCR. We observed that the expressions of these genes at the hepatic level were significantly decreased in comparison with the control samples (TIMP-1: $-80.48 \%$, $P<0.05$; TIMP-2: $-79.34 \%, P<0.05$; Fig. 4).

\section{Effects of zearalenone toxin on the gene expression of PPAR $\gamma$ in swine liver}

In order to investigate the possible involvement of nuclear receptor PPAR $\gamma$ as a signal molecule in inflammatory processes, we analysed the expression of $P P A R \gamma$ gene in swine liver using real-time PCR. The present experiment demonstrated that after dietary exposure to ZEA toxin, the expression of PPAR $\gamma$ gene was not modified in the liver of the intoxicated piglets (a decrease of $-23.33 \%$ in comparison with the control group) (Table 4 ).

Effects of dietary zearalenone on the gene expressions of transcription signalling molecules mitogen-activated protein kinases (mitogen-activated protein kinase kinase kinase 7/mitogen-activated protein kinase 14/mitogenactivated protein kinase $8 /$ mitogen-activated protein kinase 9) and NF- $\mathrm{B} 1$ in swine liver

To further investigate the involvement of MAPK and/or NF- $\mathrm{B}$ signalling pathways in ZEA-induced abnormalities in the liver, we evaluated the expressions of TAK1, $p 38 \alpha, J N K 1 / J N K 2$ MAPK and $N F-\kappa B 1$ genes using real-time PCR. The present results showed that the treatment with $316 \mathrm{ppb}$ dietary ZEA significantly down-regulated the expression of $p 38 \alpha$ gene $(-74.60 \%, \quad P<0.0001)$ and that of its activator TAK1

Table 4. Effect of in vivo exposure of piglets to zearalenone (ZEA) on the gene expressions of nuclear receptors and mitogen-activated protein kinases (MAPK) in the hepatic tissue (Mean values with their standard errors)

\begin{tabular}{|c|c|c|c|c|c|}
\hline \multirow{3}{*}{$\begin{array}{l}\text { Gene } \\
\text { expressions } \ddagger\end{array}$} & \multicolumn{5}{|c|}{ Experimental groups $\dagger$} \\
\hline & \multicolumn{2}{|c|}{ Control } & \multicolumn{2}{|c|}{$\begin{array}{l}\text { ZEA } \\
\text { contamination }\end{array}$} & \multirow{2}{*}{$\begin{array}{l}\text { ZEA effect } \\
P\end{array}$} \\
\hline & Mean & SEM & Mean & SEM & \\
\hline \multicolumn{6}{|c|}{ Nuclear receptors } \\
\hline$P P A R \gamma$ & 1.00 & 0.2 & $1 \cdot 23$ & 0.1 & NS \\
\hline$N F-\kappa B 1$ & 1.00 & 0.3 & $0.23^{*}$ & 0.0 & 0.0013 \\
\hline \multicolumn{6}{|l|}{ MAPK } \\
\hline TAK1 & $1 \cdot 00$ & 0.5 & $0.02^{*}$ & 0.0 & $<0.0001$ \\
\hline$p 38 \alpha$ & 1.00 & 0.3 & $0 \cdot 25^{*}$ & 0.0 & $<0.0001$ \\
\hline JNK1 & 1.00 & 0.4 & 0.94 & 0.5 & NS \\
\hline JNK2 & 1.00 & 0.2 & 1.01 & 0.1 & NS \\
\hline \multicolumn{6}{|c|}{$\begin{array}{l}\text { TAK1, mitogen-activated protein kinase kinase kinase } 7 ; p 38 \alpha \text {, mitogen-activated } \\
\text { protein kinase } 14 ; J N K 1, \text { mitogen-activated protein kinase } 8 ; J N K 2 \text {, } \\
\text { mitogen-activated protein kinase } 9 .\end{array}$} \\
\hline \multirow{2}{*}{\multicolumn{6}{|c|}{$\begin{array}{l}\text { * Mean value was significantly different from that of the control group }(P<0.05 \text {; } \\
\text { one-way ANOVA followed by Fisher's test). } \\
\text { † Piglets were fed a control diet or a diet contaminated with } 316 \mu \mathrm{g} \text { of } Z E A / \mathrm{kg} \text { diet } \\
\text { for } 18 \mathrm{~d} \text {. At the end of the experiment, liver samples from all the piglets }(n 5) \\
\text { were collected and analysed for the mRNA expressions of cytokines using quan- } \\
\text { titative real-time PCR. }\end{array}$}} \\
\hline & & & & & \\
\hline \multicolumn{6}{|c|}{$\begin{array}{l}\text { † Results are expressed as fold changes after normalisation of the expression of target } \\
\text { cytokine gene to the arithmetic mean of two internally expressed reference genes. }\end{array}$} \\
\hline
\end{tabular}


$(-98.48 \%, P<0.0001)$, while the expressions of $J N K 1$ and JNK2 mRNA were not modified in the liver samples of piglets treated with dietary ZEA (6.24 and $-0.88 \%$, respectively) (Table 4). The analysis of the NF-кB1 signalling pathway showed that the expression of $N F-\kappa B 1$ gene in the liver was significantly $(P<0 \cdot 0001)$ reduced $(-77 \cdot 33 \%)$ (Table 4$)$.

The immunoblot analysis showed that the phosphorylation level of p38 MAPK was significantly reduced $(-36.37 \%$, $P<0.001)$ in the liver samples collected from piglets treated with dietary ZEA (Fig. 5).

\section{Correlations between the gene expressions of the} nuclear receptor NF- $\kappa \mathrm{B} 1$, inflammation-related markers (cytokines/matrix metalloproteinases) and signalling mitogen-activated protein kinases (mitogen-activated protein kinase kinase kinase $7 /$ mitogen-activated protein kinase 14/mitogen-activated protein kinase 8/mitogenactivated protein kinase 9) in the hepatic tissue of piglets fed the zearalenone-contaminated diet

Mathematical correlations were established in order to better understand the relationships between the expressions of signalling molecules and inflammation genes in the liver samples derived from piglets fed dietary ZEA. The linear regression analysis showed no correlation between the expressions of $P P A R \gamma$ and inflammatory-related genes (data not shown) induced by the ZEA treatment.

When a linear regression analysis was carried out using the expression of $N F-\kappa B 1$ gene as the dependent variable, we obtained good correlations between the expressions of $N F-\kappa B 1$ and pro-inflammatory cytokine genes (TNF- $\alpha: R^{2}$ $\left.0.469 ; I L-1 \beta: R^{2} 0.655\right)$ and also between those of $N F-\kappa B 1$ gene and genes coding for TIMP-1 $\left(R^{2} 0.697\right)$ and TIMP-2, respectively $\left(R^{2}\right.$ 0.582). A significantly high correlation was established between the expressions of $N F-\kappa B 1$ and $I F N-\gamma$ genes $\left(R^{2} 0 \cdot 912, P<0 \cdot 01\right.$; Table 5). Good correlations were

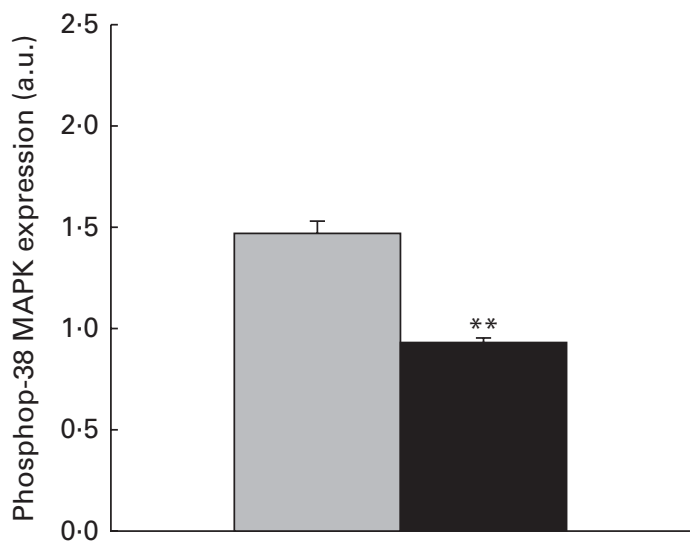

Fig. 5. Influence of dietary zearalenone (ZEA) on the p38 mitogen-activated protein kinase (MAPK) phosphorylation level in the liver of piglets. p38 MAPK phosphorylation level at Thr180/Tyr182 was determined using Western blot analysis, and it is expressed as the ratio of phospho-p38 MAPK to $\beta$-actin band intensities. Values are means for each group of piglets, with their standard errors represented by vertical bars. ${ }^{* *}$ Mean value of the ZEA-contaminated group $(\square)$ was significantly different from that of the control group ( $\square$ ) $(P<0.001$; one-way ANOVA test). a.u., Arbitrary units. also found between the expressions of $I L-10, I L-4$ and $N F-\kappa B 1$ mRNA $\left(R^{2} 0.454\right.$ for $I L-10 ; R^{2} 0.662$ for $\left.I L-4\right)$. As expected, significant correlations were found between the expressions of $N F-\kappa B 1$ and $p 38 \alpha / J N K 2$ genes $\left(R^{2} 0.951\right.$, $P<0.01$ for $p 38 \alpha ; R^{2} 0.923, P<0.001$ for $J N K 2$ ) (Table 5).

Correlations between the gene expressions of mitogenactivated protein kinases (mitogen-activated protein kinase kinase kinase $7 /$ mitogen-activated protein kinase 14/mitogen-activated protein kinase 8/mitogen-activated protein kinase 9), inflammation-related markers (cytokines/matrix metalloproteinases) and nuclear receptors (PPAR $\gamma$ ) in the hepatic tissue of piglets fed the zearalenone-contaminated diet

A linear regression analysis was used to evaluate the possible correlations between the expressions of MAPK (TAK1/p38 $\alpha$ / $J N K)$, pro/anti-inflammatory cytokine and MMP/TIMP genes in the hepatic tissue of ZEA-treated piglets. The results showed high correlations between the gene expressions of MAPK and Th1/Th2 cytokines and low correlations between the gene expressions of $I L-8$ and $I L-6$ cytokines, which are produced by different cell types (Table 6 ). High correlations were observed between the expressions of TAK1 and TNF- $\alpha$ genes $\left(R^{2} 0.846, P<0.05\right)$ and also between those of TAK1 and the other cytokine genes $\left(I L-1 \beta: R^{2} 0.614 ; I F N-\gamma: R^{2} 0 \cdot 446 ; I L-4\right.$ : $R^{2} 0.620 ; I L-6: R^{2} 0 \cdot 673$ ) (Table 6). Similarly, high linear correlations were found between the expressions of $p 38 \alpha$ and $I L-1 \beta$ $\left(R^{2} 0.634\right), I L-10\left(R^{2} 0.644\right), I L-4\left(R^{2} 0.822\right)$ and TIMP-1 $\left(R^{2} 0.679\right)$ genes, with a significant one for the expression of $I F N-\gamma$ gene $\left(R^{2} 0.766, P=0.05\right)$ and between the expressions of JNK2 and TNF- $\alpha\left(R^{2} 0.530\right), I L-1 \beta\left(R^{2} 0.584\right)$ and TIMP-2 $\left(R^{2} 0.799\right)$ genes as well as between those of JNK2 and IFN- $\gamma$ genes $\left(R^{2}\right.$ 0.986, $\left.P<0 \cdot 001\right)$ (Table 6). A significant linear correlation was also established between the expressions of $p 38 \alpha$ and JNK2 genes ( $\left.R^{2} 0.767, P=0.05\right)$ (Table 6). No correlations between the expressions of JNK1 and inflammation-related genes were found (data not shown).

\section{Discussion}

Pigs, particularly the gilts, seem to be the most sensitive animal species to ZEA and its metabolites ${ }^{(32)}$. Various studies have indicated that the female pigs are particularly sensitive to the oestrogenic effects of $\mathrm{ZEA}^{(32)}$, but there are only a few studies that have investigated the effect of ZEA on swine immune response $\mathrm{e}^{(28-33)}$ and even fewer on the effect of ZEA on the immune response in the liver. It is known that after an oral exposure, ZEA is metabolised in various tissues, particularly in the liver ${ }^{(47)}$. Situated in a unique position between the gastrointestinal tract and the systemic venous system, the liver plays a key role in immune system homeostasis ${ }^{(48)}$ being constantly exposed to food antigens (e.g. toxins), bacterial products and potential pathogens through the mesenteric circulation. Fetal liver is also a haematopoietic organ along with the adult spleen $^{(49)}$. That is why in the present study weaned piglets were exposed to $316 \mathrm{ppb}$ ZEA through the diet for $18 \mathrm{~d}$ and the significant changes produced by ZEA in the levels of several 
markers involved in the liver defence processes were investigated. The consumption of the experimentally contaminated diet did not alter animal performance.

\section{Dietary zearalenone modulates the gene expressions and protein concentrations of inflammation-related markers (cytokines/matrix metalloproteinases) in swine liver}

The consumption of the ZEA-contaminated diet dramatically reduced the concentrations of several pro-inflammatory cytokines (TNF- $\alpha$, IL-8, IL-1 $\beta$, IL-6 and IFN- $\gamma$ ) as well as their gene expressions in the liver of piglets fed the ZEAcontaminated diet (Figs. 1 and 2). Very importantly, ZEA also decreased the expressions of IFN- $\gamma$ (at the gene and protein levels) and Th1 master cytokines, which play a major role in the host defence against intracellular infections. The ingestion of the ZEA-contaminated diet also led to the down-regulation of the gene expressions and protein levels of the characteristic Th2 cytokine (IL-4) involved in humoral immune response. The dietary ZEA seems to have had no effect on the gene expression of the anti-inflammatory cytokine $I L-10$, but it altered the protein concentration of this cytokine in the hepatic tissue. These results are in agreement with the results of the study of Wang et al. ${ }^{(16)}$, who found the alteration in the expressions of cytokines (IL-2, IL-6 and IFN- $\gamma$ ) in chicken splenocytes to be associated in vitro with increasing concentrations of ZEA. It has been reported that the genotoxic effect of ZEA is due to the DNA fragmentation brought about by it, which leads to the inhibition of protein synthesis ${ }^{(50,51)}$. In other studies, ZEA and its derivatives have also been described as the suppressors ${ }^{(31,52)}$ of the expressions of pro-inflammatory cytokines and as inducers of DNA fragmentation ${ }^{(53)}$. DNA fragmentation was among the chronological succession of some events that characterised the toxicity of ZEA in human hepatocarcinoma cells ${ }^{(53)}$. Besides ZEA, Fusarium sp. produces toxins such as DON or fumonisin B1, which are also immunomodulators, being able to decrease or increase the production of cytokines in the liver and other tissues. For example, in vivo ingestion of $2 \cdot 8 \mu \mathrm{mol}$ fumonisin $\mathrm{B} 1 / \mathrm{kg}$ body weight per $\mathrm{d}$ decreased the expressions of IL-6, IL-10, IL-18 and IFN- $\gamma$ in the liver of piglets, while the expressions of IL-1 $\beta$ and IL-8 were increased $^{(36)}$. DON induced modest expressions of TNF- $\alpha$, IL-6 and IL-1 $\beta$ in the liver relative to the spleen ${ }^{(54,55)}$, but increased the expressions of Th2-mediated cytokines IL-4 and IL- 6 and suppressed those of IFN- $\boldsymbol{\gamma}$ and Th1 cytokine in Peyer's patches of mice infected with reovirus exposed previously to DON contamination ${ }^{(56)}$. This divergent effect may be due to the differences in their toxicities and animal models.

In the present study, the ZEA-contaminated diet exerted a significant inhibitory effect on the gene expressions of other hepatic inflammatory mediators, MMP and TIMP (Fig. 4). The gelatin zymography analysis also showed a decrease in MMP-2 and MMP-9 gelatinolytic activities in both the liver and plasma samples obtained from piglets fed the ZEAcontaminated diet. Only a few studies have analysed the effect of mycotoxins on MMP activity and/or secretion, and to our knowledge, this is the first study to investigate the 
effect of ZEA on metalloproteinases and their inhibitors in pigs. But other studies have shown that in mice, $\mathrm{T}-2$ toxin induced alterations in blood-brain barrier permeability, mediated partially through the activation of MMP-9 ${ }^{(57)}$, while in humans, rubratoxin $\mathrm{B}$ exhibited inhibitory activities against MMP-2 and MMP-9 in fibrosarcoma HT 1080 cells $^{(58)}$. By contrast, Gagliano et al. ${ }^{(59)}$ demonstrated that chronic treatment with ochratoxin A did not affect the protein levels of MMP-2 and MMP-9 in rat liver.

\section{Dietary zearalenone alters the gene expressions and protein concentrations of transcription signalling molecules in the hepatic tissue of piglets fed the zearalenone-contaminated diet}

We further investigated whether the alterations induced by ZEA in the liver implied nuclear receptors (PPAR $\gamma$ and NF-кB1) and MAPK (TAK1, p38 $\alpha$, JNK1 and JNK2) to be sentinel effectors in the signal transduction pathways of inflammation. PPAR $y$ is a member of the nuclear receptor superfamily PPAR involved in the regulation of the immune response, particularly in inflammation control; the majority of studies support an anti-inflammatory role for PPAR $\gamma^{(60-62)}$ in terms of cytokine regulation. In the present study, piglets fed the diet contaminated with $316 \mathrm{ppb}$ of ZEA exhibited only a slight increase in the expression of PPAR $\gamma$ gene and, despite the significant decrease in the expressions of proinflammatory cytokine genes, no correlation between the expressions of PPAR $\gamma$ and pro-inflammatory cytokine genes was found in the liver of piglets fed the ZEA-contaminated diet. Similarly, Ding et $a l^{(27)}$ found that PPARy was not among the nuclear receptors activated in vitro by $10 \mu \mathrm{m}$ of ZEA in CV-1 cells at the mRNA level. In a docking study, Prouillac et al. ${ }^{(63)}$ suggested that ZEA, which has smaller size and lower flexibility, could not establish high interactions with this receptor because of its high flexibility and of the particular conformation of its ligand-binding site (much larger bended ligand-binding pocket than other nuclear receptors). Conversely, PPAR $\gamma$ could be activated by other mycotoxins and feed compounds. Moon et al. ${ }^{(64)}$ proved that DON induced the production of IL- 8 through the activation of PPAR $y$ and MAPK (extracellular signal-regulated protein kinases $1 / 2$ and early-growth response protein 1), while Zhan et $a l .{ }^{(60)}$ demonstrated that $n$-3 PUFA from the linseed diet lead to a significant increase in the expression of PPAR $\gamma$ gene with significant negative linear correlations between the expressions of PPAR $\gamma$ and pro-inflammatory cytokine genes in the muscle and spleen of fattening pigs.

The study of Ding et al. ${ }^{(27)}$ showed that ZEA binds to hepatic pregnane $\mathrm{X}$ receptor and serves as a direct ligand for the NF-кB1 receptor, other important transcription factors involved in the pro-inflammatory signal transduction pathway. NF-кB has been reported to induce the transcription of various cytokine genes such as $I L-1, I L-2$ and $I L-\sigma^{(49)}$. It has been shown in mouse hepatocytes that the activation of pregnane $\mathrm{X}$ receptor decreases the transcriptional activity of NF- $\mathrm{B}^{(65)}$. In the present study, we showed that dietary consumption of $316 \mathrm{ppb}$ ZEA caused a significant decrease in the 
expression of $N F-\kappa B 1$ gene. This was associated with a significant decrease in the expressions of pro-inflammatory cytokines and a high correlation between them, which was significant for the expression of IFN- $\gamma$. A significant reduction in the translocation of NF- $\mathrm{KB}$ has also been demonstrated by treatments with other mycotoxins, gliotoxins in lipopolysaccharide-stimulated dendritic cells (DC) ${ }^{(66,67)}$ and citrinin in MES-13 cells, followed by the suppression of the expressions of IFN- $\gamma$, NO and inducible NO synthase ${ }^{(68)}$. No effect on the expression of NF- $\mathrm{B}$ was observed on treatment with patulin in lipopolysaccharide-stimulated $\mathrm{DC}^{(66)}$

The MAPK family of serine/threonine kinases is a key component of the signalling pathways that regulate a variety of intracellular processes, including growth, differentiation and the response to cytokines and stress ${ }^{(69)}$. Thus, p38 $\alpha$ MAPK plays a role in the induction of cell cycle and cell development and in the inducible expressions of many pro-inflammatory cytokine genes, whereas JNK proteins are involved in cytokine production, inflammatory responses, apoptosis, actin organisation and metabolism ${ }^{(70,71)}$. TAK1 is also a key molecule in the pro-inflammatory signalling pathways, being responsible for the phosphorylation and activation of several kinases, which in turn activate both MAPK (JNK and p38 $\alpha$ ) and NF-кB (IкB kinase $)^{(72,73)}$. The intake of $316 \mathrm{ppb}$ ZEA diet decreased the expressions of $p 38 \alpha$ MAPK and JNK1 genes as well as that of their activator TAK1 in the liver of piglets from the experimental group, while that of JNK2 gene remained unaffected by ZEA contamination. Similar to that found for the expression of $N F-\kappa B 1$ gene, significantly high correlations were found between the expressions of $p 38 \alpha$ MAPK, JNK2 and $I F N-\gamma$ genes. A low correlation was found between the expressions of TAK1 and $p 38 \alpha$ MAPK genes, which may be due to the intercalation of other MAPK between them. It seems that the effects of ZEA on MAPK depend on the type of the cells. The study of $\mathrm{Yu}$ et al. $^{(74)}$ showed that ZEA induced cytotoxicity in RAW264.7 cells through the activation of p53 and MAPK (JNK/p38) signalling pathways. In contrast, the phosphorylation state of MAPK has been reported to be strongly reduced in pig endometrial cells by $\beta$-ZEA, a ZEA derivative ${ }^{(75)}$, similar to that observed in the present study, in which ZEA also significantly reduced the protein expression of phosphorylated p38 in porcine hepatic cells. Other mycotoxins, e.g. DON, have been found to induce the activation of MAPK in many other cell types, macrophages $^{(76)}$ and Jurkat cells ${ }^{(77)}$ and, recently, Pinton et al. ${ }^{(78)}$ have demonstrated that DON and acetylated DON modulated differently the expressions of MAPK in pig enterocytes with respect to their concentrations and may thus influence their inflammatory and anti-inflammatory responses. These opposite results suggest that structurally different mycotoxins employ different mechanisms while exerting their effects on molecular signalling pathways.

In summary, the results presented herein suggest that ZEA is not only a powerful oestrogen endocrine disruptor, but also a hepatoimmunotoxic Fusarium toxin in pigs. By inhibiting the gene expressions and protein concentrations of MAPK (TAK1/JNK/p38) and NF- $\mathrm{kB}$, the key effectors of signal transduction pathways, this mycotoxin caused severe hepatic immunosuppression (significant reduction in the expressions and protein concentrations of several markers of pro- and anti-inflammatory processes), which might have important consequences during an infection process. The present results suggest that the toxic action of ZEA begins in the upstream of the signal transduction pathway of MAPK by the inhibition of the expression of TAK1 gene, an activator of MAPK and NF-кB. This hypothesis is also supported by the study of Ninomiya-Tsuji et al. ${ }^{(72)}$, who showed that 5Z-7-oxozeaenol, another natural fungal metabolite, induced a high inhibition of TAK1 kinase. Exposure of cells to 5Z-7-oxozeaenol has been reported to inhibit the catalytic activity of TAK1 and consequently p38, JNK, IкB kinase and NF-кB by interacting with the ATP-binding site of TAK1. In the other possible scenario, the repression of $\mathrm{NF}-\kappa \mathrm{B}$ could result from the oestrogenic activity of ZEA. It is known that autocrine hormones such as PG, e.g. 15d-PGJ2 (prostanoid 15-deoxy-PGJ2), can repress $\mathrm{NF}-\kappa \mathrm{B}$ activity independent of PPAR $\gamma$ by inhibiting IкB kinase and/or by alkylating p50-65 NF- $\mathrm{BB}$ heterodimers ${ }^{(79)}$

Considering that ZEA is a frequent contaminant of animal feed and human food preparations, the present results might have clinical relevance and could contribute to the establishment of the maximal limit of tolerance in feeds for pigs.

\section{Acknowledgements}

The authors thank Dr Mihaela Mocanu and Dr Gina Manda from the National Institute of Research and Development in the Pathology Domain and Biomedical Sciences 'Victor Babes' from Bucharest for their help with the immunoblot analysis.

The present study was supported by funds from PNII - IDEI 101/2011-2014 and PNII - PARTENERIATE 102/2012-2015, granted by the Romanian Ministry of Research and Technology. The Romanian Ministry of Research and Technology had no role in the design and analysis of the present study or in the writing of this article.

The contribution of each author was as follows: G. C. P. wrote the manuscript, carried out the quantitative real-time PCR analyses and cytokine and Western blot determinations, and analysed the data; M. A. G. and D. E. M. contributed to the progress of the in vivo experiment (sample collection and preparation); M. S. carried out the cytokine ELISA measurement; F. I. R. conducted the HPLC for ZEA analyses in compound feed; I. T. conducted and designed the research experiment and contributed to manuscript preparation.

The authors have no conflicts of interest.

\section{References}

1. Richard JL (2007) Some major mycotoxins and their mycotoxicoses - an overview. Int J Food Microbiol 119, 3-10.

2. Bennett JW \& Klich M (2003) Mycotoxins. Clin Microbiol Rev 16, 497-516.

3. MacDonald SJ, Anderson S, Brereton P, et al. (2005) Determination of zearalenone in barley, maize and wheat flour, polenta, and maize-based baby food by immunoaffinity column cleanup with liquid chromatography: interlaboratory study. $A O A C$ Int 88, 1733-1740. 
4. Engelhardt G, Barthel J \& Sparrer D (2006) Fusarium mycotoxins and ochratoxin $\mathrm{A}$ in cereals and cereal products: results from the Bavarian Health and Food Safety Authority in 2004. Mol Nutr Food Res 50, 401-405.

5. Tabuc C, Marin D, Guerre P, et al. (2009) Molds and mycotoxin content of cereals in southeastern Romania. J Food Prot 72, 662-665.

6. CCFAC (2000) Codex Committee on Food Additives and Contaminants. Posting Date. Joint FAO/WHO Expert Committee on Food Additives: Position Paper on Zearalenone. Publication CCFAC 00/19. Rome: Codex Alimentarius Commission.

7. Tiemann U \& Dänicke S (2007) In vivo and in vitro effects of the mycotoxins zearalenone and deoxynivalenol on different non-reproductive and reproductive organs in female pigs: a review. Food Addit Contam 24, 306-314.

8. Kuiper GM, Lemmen JG, Carlsson B, et al. (1998) Interaction of estrogenic chemicals and phytoestrogens with estrogen receptor $\beta$. Endocrinology 139, 4252-4263.

9. JECFA (2000) Zearalenone. In: Safety Evaluation of Certain Food Additives and Contaminants. WHO/FAO Food Additives Series 44 [Joint FAO/WHO Expert Committee on Food Additives, editor]. Geneva: WHO (IPCS - International Programme on Chemical Safety).

10. Kuiper-Goodman T, Scott PM \& Watanabe H (1987) Risk assessment of the mycotoxin zearalenone. Regul Toxicol Pharmacol 7, 253-306.

11. Lioi MB, Santoro A, Barbieri R, et al. (2004) Ochratoxin and zearalenone: a comparative study on genotoxic effects and cell death induced in bovine lymphocytes. Mutat Res $\mathbf{5 5 7}$, 19-24.

12. Abid-Essefi S, Baudrimont I, Hassen W, et al. (2003) DNA fragmentation, apoptosis and cell cycle arrest induced by zearalenone in cultured DOK, Vero and Caco-2 cells: prevention by vitamin E. Toxicology 192, 237-248.

13. Abid-Essefi S, Ouanes Z, Hassen W, et al. (2004) Cytotoxicity, inhibition of DNA and protein syntheses and oxidative damage in cultured cells exposed to zearalenone. Toxicol In Vitro 18, 467-474.

14. Atkinson HA \& Miller K (1984) Inhibitory effect of deoxynivalenol, 3-acetyldeoxynivalenol and zearalenone on induction of rat and human lymphocyte proliferation. Toxicol Lett 23, 215-221.

15. Luongo D, De Luna R, Russo R, et al. (2008) Effects of four Fusarium toxins (fumonisin $\mathrm{B}(1)$, alpha-zearalenol, nivalenol and deoxynivalenol) on porcine whole-blood cellular proliferation. Toxicon 52, 156-162.

16. Wang YC, Deng JL, Xu SW, et al. (2012) Effects of zearalenone on IL-2, IL-6, and IFN- $\gamma$ mRNA levels in the splenic lymphocytes of chickens. ScientificWorldJournal, 2012 (article ID 567327).

17. Ouanes Z, Abid S, Ayed I, et al. (2003) Induction of micronuclei by zearalenone in Vero monkey kidney cells and in bone marrow cells of mice: protective effect of Vitamin E. Mutat Res 538, 63-70.

18. Bouaziz C, Martel C, Sharaf el dein O, et al. (2009) Fusarial toxin-induced toxicity in cultured cells and in isolated mitochondria involves PTPC-dependent activation of the mitochondrial pathway of apoptosis. Toxicol Sci $\mathbf{1 1 0}$, 363-375.

19. Zourgui L, Golli EE, Bouaziz C, et al. (2008) Cactus (Opuntia ficus-indica) cladodes prevent oxidative damage induced by the mycotoxin zearalenone in Balb/C mice. Food Chem Toxicol 46, 1817-1824.
20. Kiessling KH \& Pettersson H (1978) Metabolism of zearalenone in rat liver. Acta Pharmacol Toxicol (Copenh) $\mathbf{4 3}$, 285-290.

21. Jiang SZ, Yang ZB, Yang WR, et al. (2011) Effects of purified zearalenone on growth performance, organ size, serum metabolites, and oxidative stress in postweaning gilts. J Anim Sci 89, 3008-3015.

22. Hou Y-J, Zhao Y-Y, Xiong B, et al. (2013) Mycotoxincontaining diet causes oxidative stress in the mouse. PLOS ONE 8, e60374.

23. NTP (National Toxicology Program) (1982) Carcinogenesis Bioassay of Zearalenone in F 344/N Rats and F6C3F1 Mice. National Toxicology Program Technical Report Series no. 235. Research Triangle Park, NC: Department of Health and Human Services.

24. Maaroufi K, Chekir L, Creppy EE, et al. (1996) Zearalenone induces modifications of haematological and biochemical parameters in rats. Toxicon 34, 535-540.

25. Conkova E, Laciakova A, Pastorova B, et al. (2001) The effect of zearalenone on some enzymatic parameters in rabbits. Toxicol Lett 121, 145-149.

26. Wang DF, Zhang NY, Peng YZ, et al. (2010) Interaction of zearalenone and soybean isoflavone on the development of reproductive organs, reproductive hormones and estrogen receptor expression in prepubertal gilts. Anim Reprod Sci 122, 317-323.

27. Ding X, Lichti K \& Staudinger JL (2006) The mycoestrogen zearalenone induces CYP3A through activation of the pregnane X receptor. Toxicol Sci $\mathbf{9 1}, 448-455$.

28. The European Food Safety Authority (EFSA) (2004) Opinion of the Scientific Panel on contaminants in the food chain on a request from the commission related to zearalenone as undesirable substance in animal feed. EFSA J 89, 1-35.

29. Stec J, Zmudzki J, Rachubik J, et al. (2009) Effects of aflatoxin B1, ochratoxin A, patulin, citrinin, and zearalenone on the in vitro proliferation of pig blood lymphocytes. Bull Vet Inst Pulawy 53, 129-134.

30. Marin DE, Taranu I, Burlacu R, et al. (2010) Effects of zearalenone and its derivatives on the innate immune response in swine. Toxicon 56, 956-963.

31. Marin DE, Taranu I, Burlacu R, et al. (2011) Effects of zearalenone and its derivatives on porcine immune response. Toxicol In Vitro 25, 1981-1988.

32. The European Food Safety Authority (EFSA) (2011) Scientific opinion on the risks for public health related to the presence of zearalenone in food. EFSA J 9, 2197. http://www.efsa. europa.eu.

33. Taranu I, Marin DE, Manda G, et al. (2011) Assessment of the potential of a boron-fructose additive in counteracting the toxic effect of Fusarium mycotoxins. Br J Nutr 106, 398-407.

34. Grenier B, Bracarense AP, Schwartz HE, et al. (2012) The low intestinal and hepatic toxicity of hydrolyzed fumonisin B1 correlates with its inability to alter the metabolism of sphingolipids. Biochem Pharmacol 83, 1465-1473.

35. Von der Hardt K, Kandler MA, Brenn G, et al. (2004) Comparison of aerosol therapy with different perfluorocarbons in surfactant-depleted animals. Crit Care Med 32, 1200-1206.

36. Royaee AR, Husmann RJ, Dawson HD, et al. (2004) Deciphering the involvement of innate immune factors in the development of the host response to PRRSV vaccination. Vet Immunol Immunopathol 102, 199-216.

37. Meurens F, Berri M, Auray G, et al. (2009) Early immune response following Salmonella enterica subspecies enterica 
serovar Typhimurium infection in porcine jejunal gut loops. Vet Res 40, 5 .

38. Zeni P, Doepker E, Topphoff US, et al. (2007) MMPs contribute to TNF- $\alpha$-induced alteration of the blood-cerebrospinal fluid barrier in vitro. Am J Physiol Cell Physiol 293, C855-C864.

39. Singh NK, Chae HS, Hwang IH, et al. (2007) Trans differentiation of porcine satellite cells to adipoblasts with ciglitizone. J Anim Sci 85, 1126-1135.

40. Primer 3. http://frodo.wi.mit.edu/cgi-bin/primer3/primer3_ www.cgi (accessed May 2012).

41. Gesslein B, Håkansson G, Carpio R, et al. (2010) Mitogenactivated protein kinases in the porcine retinal arteries and neuroretina following retinal ischemia-reperfusion. Mol Vis 16, 392-407.

42. Chowdhury SR, King DE, Willing BP, et al. (2007) Transcriptome profiling of the small intestinal epithelium in germfree versus conventional piglets. BMC Genomics 8, 215.

43. Devriendt B, Gallois M, Verdonck F, et al. (2009) The food contaminant fumonisin $\mathrm{B} 1$ reduces the maturation of porcine $\mathrm{CD} 11 \mathrm{R} 1^{+}$intestinal antigen presenting cells and antigenspecific immune responses, leading to a prolonged intestinal ETEC infection. Vet Res $\mathbf{4 0}, 40$.

44. Hyland KA, Brown DR \& Murtaugh MP (2006) Salmonella enterica serovar Choleraesuis infection of the porcine jejunal Peyer's patch rapidly induces IL-1beta and IL-8 expression. Vet Immunol Immunopathol 109, 1-11.

45. Litvak KJ \& Schmittgen TD (2001) Analysis of relative gene expression data using real-time quantitative PCR and the 2(-Delta Delta C(T)) method. Methods 25, 402-408.

46. Pistol G, Matache C, Calugaru A, et al. (2007) Roles of CD147 on T lymphocytes activation and MMP-9 secretion in systemic lupus erythematosus. J Cell Mol Med 11, 339-348.

47. Dänicke S, Swiech E, Buraczewska L, et al. (2005) Kinetics and metabolism of zearalenone in young female pigs. J Anim Physiol Anim Nutr (Berl) 89, 268-276.

48. Lapierre P \& Alvarez F (2007) The liver: an organ of the immune system? Med Sci 23, 985-990.

49. Pahl HL, Krauss B, Schulze-Osthoff K, et al. (1996) The immunosuppressive fungal metabolite gliotoxin specifically inhibits transcription factor NF-kappaB. I Exp Med 183, $1829-1840$

50. Salah-Abbès JB, Abbès S, Haous Z, et al. (2009) Raphanus sativus extract prevents and ameliorates zearalenoneinduced peroxidative hepatic damage in $\mathrm{Balb} / \mathrm{c}$ mice. J Pharm Pharmacol 61, 1545-1554.

51. Abid-Essefi S, Bouaziz C, Golli-Bennour EE, et al. (2009) Comparative study of toxic effects of zearalenone and its two major metabolites alpha-zearalenol and beta-zearalenol on cultured human Caco-2 cells. J Biochem Mol Toxicol 23, 233-243.

52. Salah-Abbès BJ, Abbès S, Houas Z, et al. (2008) Zearalenone induces immunotoxicity in mice: possible protective effects of radish extract (Raphanus sativus). J Pharm Pharmacol 60, 761-770

53. Gazzah AC, El Golli Bennour E, Bouaziz C, et al. (2010) Sequential events of apoptosis induced by zearalenone in cultured hepatocarcinoma cells. Mycotoxin Res 26, 187-197.

54. Azcona-Olivera JI, Ouyang Y, Murtha J, et al. (1995) Induction of cytokine mRNAs in mice after oral exposure to the trichothecene vomitoxin (deoxynivalenol): relationship to toxin distribution and protein synthesis inhibition. Toxicol Appl Pharmacol 133, 109-120.

55. Pestka JJ \& Amuzie CJ (2008) Tissue distribution and proinflammatory cytokine gene expression following acute oral exposure to deoxynivalenol: comparison of weanling and adult mice. Food Chem Toxicol 46, 2826-2831.

56. Li M, Cuff CF \& Pestka J (2005) Modulation of murine host response to enteric reovirus infection by the trichothecenedeoxynivalenol. Toxicol Sci 87, 134-145.

57. Ravindran J, Agrawal M, Gupta N, et al. (2011) Alteration of blood-brain barrier permeability by T-2 toxin: role of MMP-9 and inflammatory cytokines. Toxicology $\mathbf{2 8 0}$ $44-52$.

58. Wang T, Zhang Y, Wang Y, et al. (2007) Anti-tumor effects of rubratoxin $\mathrm{B}$ on cell toxicity, inhibition of cell proliferation, cytotoxic activity and matrix metalloproteinase-2,9. Toxicol In Vitro 21, 646-650.

59. Gagliano N, Donne ID, Torri C, et al. (2006) Early cytotoxic effects of ochratoxin A in rat liver: a morphological, biochemical and molecular study. Toxicology 225, 214-224.

60. Zhan ZP, Huang FR, Luo J, et al. (2009) Duration of feeding linseed diet influences expression of inflammationrelated genes and growth performance of growing-finishing barrows. J Anim Sci 87, 603-611.

61. Jiang C, Ting AT \& Seed B (1998) PPAR-gamma agonists inhibit production of monocyte inflammatory cytokines. Nature 391, 82-86.

62. Cuzzocrea S, Wayman NS, Mazzon E, et al. (2002) The cyclopentenone prostaglandin 15-deoxy-Delta $(12,14)$-prostaglandin J(2) attenuates the development of acute and chronic inflammation. Mol Pharmacol 61, 997-1007.

63. Prouillac C, Koraichi F, Videmann B, et al. (2012) In vitro toxicological effects of estrogenic mycotoxins on human placental cells: structure-activity relationships. Toxicol Appl Pharmacol 259, 366-375.

64. Moon Y, Yang H \& Park SH (2008) Hypo-responsiveness of interleukin-8 production in human embryonic epithelial intestine 407 cells independent of NF-kappaB pathway: new lessons from endotoxin and ribotoxic deoxynivalenol. Toxicol Appl Pharmacol 231, 94-102.

65. Zhou C, Tabb MM, Nelson EL, et al. (2006) Mutual repression between steroid and xenobiotic receptor and NF-кB signaling pathways links xenobiotic metabolism and inflammation. J Clin Invest 116, 2280-2289.

66. Schütze N, Lehmann I, Bönisch U, et al. (2010) Exposure to mycotoxins increases the allergic immune response in a murine asthma model. Am J Respir Crit Care Med 181, 1188-1199.

67. Wilson SJ, Leone BA, Anderson D, et al. (1999) Immunohistochemical analysis of the activation of NF- $\mathrm{KB}$ and expression of associated cytokines and adhesion molecules in human models of allergic inflammation. $J$ Pathol 189, $265-272$.

68. Liu BH, Chi JY, Hsiao YW, et al. (2010) The fungal metabolite, citrinin, inhibits lipopolysaccharide/interferon$\gamma$-induced nitric oxide production in glomerular mesangial cells. Int Immunopharmacol 10, 1608-1615.

69. Johnson GL \& Lapadat R (2002) Mitogen-activated protein kinase pathways mediated by ERK, JNK, and p38 protein kinases. Science 298, 1911-1912.

70. Erkel G, Rether J, Anke T, et al. (2003) S14-95, a novel inhibitor of the JAK/STAT pathway from a Penicillium species. J Antibiot (Tokyo) 56, 337-343.

71. Raman M, Chen W \& Cobb MH (2007) Differential regulation and properties of MAPKs. Oncogene 26, 3100-3112.

72. Ninomiya-Tsuji J, Kajino T, Ono K, et al. (2003) A resorcylic acid lactone, 5Z-7-oxozeaenol, prevents inflammation by inhibiting the catalytic activity of TAK1 MAPK kinase kinase. J Biol Chem 278, 18485-18490. 
73. Ninomiya-Tsuji J, Kishimoto K, Hiyama A, et al. (1999) The kinase TAK1 can activate the NIK-I kappaB as well as the MAP kinase cascade in the IL-1 signalling pathway. Nature 398, 252-256.

74. Yu JY, Zheng ZH, Son YO, et al. (2011) Mycotoxin zearalenone induces AIF- and ROS-mediated cell death through p53- and MAPK-dependent signaling pathways in RAW264.7 macrophages. Toxicol In Vitro 25, 1654-1663.

75. Wollenhaupt K, Jonas L, Tiemann U, et al. (2004) Influence of the mycotoxins alpha- and beta-zearalenol (ZOL) on regulators of cap-dependent translation control in pig endometrial cells. Reprod Toxicol 19, 189-199.

76. Pestka J \& Zhou HR (2006) Toll-like receptor priming sensitizes macrophages to proinflammatory cytokine gene induction by deoxynivalenol and other toxicants. Toxicol Sci 92, 445-455.

77. Pestka JJ, Uzarski RL \& Islam Z (2005) Induction of apoptosis and cytokine production in the Jurkat human $\mathrm{T}$ cells by deoxynivalenol: role of mitogen-activated protein kinases and comparison to other 8-ketotrichothecenes. Toxicology 206, 207-219.

78. Pinton P, Tsybulskyy D, Lucioli J, et al. (2012) Toxicity of deoxynivalenol and its acetylated derivatives on the intestine: differential effects on morphology, barrier function, tight junction proteins, and mitogen-activated protein kinases. Toxicol Sci 130, 180-190.

79. Szanto A \& Nagy L (2008) The many faces of PPARgamma: anti-inflammatory by any means? Immunobiology $\mathbf{2 1 3}$, 789-803. 